\title{
Spontaneously Active Cells Isolated from the Sino-atrial and Atrio-ventricular Nodes of the Rabbit Heart
}

\author{
Junichi TANIGUChI, * Shinichiro KoKubun, ** Akinori Noma, \\ and Hiroshi IrISAwA \\ National Institute for Physiological Sciences, Okazaki, Aichi, 444 Japan
}

\begin{abstract}
Single cells or cell clusters composed of 3-10 cells were isolated from the $\mathrm{S}-\mathrm{A}$ and $\mathrm{A}-\mathrm{V}$ nodes of the rabbit heart by coronary perfusion of collagenase dissolved in Ca-free Tyrode solution $(0.04 \%$, for $1 \mathrm{hr}$ ). For comparison, atrial and ventricular cells were also isolated from the same heart. Shapes of the isolated nodal cell were either rod or round and nodal cells were slightly smaller than ventricular cells. Spontaneous activity was observed in both rod and round nodal cells. The action potentials had the configurations similar to those recorded from larger conventional preparations. The membrane current recorded from the small nodal cell clusters $(5-10$ cells) by the two-microelectrode voltage clamp technique showed a time course similar to that of previous recordings from conventional preparations, but the amplitude of the currents was 5-10 times smaller. The isolated cells showed normal sensitivities to both acetylcholine and epinephrine. Findings given in this study indicate that the isolated cells maintain the typical membrane characteristics of the nodal cells and that they are suitable for electrophysiological studies of the cardiac pacemaker cell.
\end{abstract}

Since the pioneering work done by VAHOUNY et al. (1970) of isolating the cardiac cell from adult hearts, the isolation procedure of the ventricular cell has been improved, and now it has become possible to record the action potentials from an isolated myocardial cell, which are similar to those recorded from the intact heart. Recent electrophysiological work on the isolated ventricular cell shows that the isolated cells have distinct advantages over tissue preparations for studies on membrane excitability. In fact, for the first time the kinetics of the rapid sodium current (LEE et al., 1979; BROWN et al., 1980) as well as the slow inward current (ISENBERG and KLÖCKNER, 1980) have been well analysed in the single cell. This

\footnotetext{
Received for publication March 6, 1981

* On leave from the Department of Biology, Faculty of Science, Osaka University, Toyonaka, Osaka, 560 Japan

** On leave from the Department of Physiology, Jikei University School of Medicine, Minato-ku, Tokyo, 105 Japan

谷口淳一, 国分真一朗, 野間昭典, 入沢 宏
} 
is mainly because the spatial clamp has improved in comparison with the previous tissue preparations. The same rationale should hold true for the studies not only of the spontaneous electrical activity of the nodal cells but also of the regulation of the spontaneous rhythm by neurotransmitters, because the voltage clamp experiments gave much useful information for these analyses (NOMA and IRISAWA, 1976a, b; Noma et al., 1977, 1979; YanAGIHARA and IrISAWA, 1980a, b; DiFranCESCO et al., 1979; Brown and Difrancesco, 1980; Noma and Trautwein, 1978). However, the experiments were always evaluated with certain limitations arising from the multicellular characteristics of the tissue preparations. Furthermore, even in simple recording of acetylcholine (ACh)-induced hyperpolarization, it was found that the time course was largely influenced by the drug diffusion and cholinesterase activity in the intercellular space (OSTERRIEDER et al., 1981). Thus, for further investigation it is necessary to develop the isolated cell preparations from the intrinsic pacemaker tissue which show both spontaneous action potentials and sensitivities to the neurotransmitters comparable to the conventional preparations.

In the present study, we isolated single cells and cell clusters consisting of 3-10 cells from both the S-A node and the A-V node by coronary perfusion of collagenase. These cells were examined on size, spontaneous action potential, membrane current and sensitivities to $\mathrm{ACh}$ and epinephrine. For comparison, the isolated atrial and ventricular cells from the same heart were also investigated.

\section{MATERIALS AND METHODS}

Preparation of isolated single cells or cell clusters. Rabbits, weighing 1.0$1.5 \mathrm{~kg}$, were anesthetized with pentobarbital sodium $(40 \mathrm{mg} / \mathrm{kg}$ weight $)$. The chest was opened and the aorta was cannulated in situ to perfuse the coronary artery of the heart (Langendorff perfusion) with Tyrode solution containing in $\mathrm{mM} ; \mathrm{NaCl}$ 136.9, $\mathrm{NaHCO}_{3}$ 11.9, $\mathrm{KCl} 5.4, \mathrm{CaCl}_{2}$ 1.8, $\mathrm{MgCl}_{2}$ 0.53, $\mathrm{NaH}_{2} \mathrm{PO}_{4}$ 0.33, HEPES 5.0, and $\mathrm{pH}$ was adjusted to 7.3-7.4. The heart was then dissected out and was hung in a moist and warm chamber $(4.5 \mathrm{~cm}$ in diameter and $10 \mathrm{~cm}$ in height) where the perfusion was continued at hydrostatic pressure of $65 \mathrm{~cm}$. After the blood was washed out, the perfusate was replaced by a Ca-free Tyrode solution. The Cafree Tyrode was made simply by omitting $\mathrm{CaCl}_{2}$ from the Tyrode solution. Following perfusion of about $100 \mathrm{ml}$ of the Ca-free Tyrode, the perfusate was switched to the Ca-free Tyrode $(50 \mathrm{ml})$ containing $0.4 \mathrm{mg} / \mathrm{ml}$ collagenase (Sigma, Type 1), which was recirculated using a peristaltic pump. After perfusion of collagenase for $60 \mathrm{~min}$, washing out was done with $100 \mathrm{ml}$ of high $\mathrm{K}$-low $\mathrm{Cl}$ solution (storage solution) containing in $\mathrm{mm}$; taurine 10 , oxalic acid 10 , glutamic acid $70, \mathrm{KCl} 25$, $\mathrm{KH}_{2} \mathrm{PO}_{4} 10$, HEPES 10 , glucose 11 , EGTA 0.5 , and $\mathrm{pH}$ was adjusted to 7.4 by adding $\mathrm{KOH}$ (Isenberg, personal communication). In this storage solution the S-A and $\mathrm{A}-\mathrm{V}$ nodal tissues were dissected out and were used in the experiment or stored at $4^{\circ} \mathrm{C}$ for later experiments. The atria and ventricles were also incubated for more 
than $1 \mathrm{hr}$ in the same condition and used in the experiments. The temperature of all perfusates was kept at $36-37^{\circ} \mathrm{C}$ during Langendorff perfusion.

Before each experiment, a small piece of tissue was dissected $(2 \times 2 \mathrm{~mm})$ from the same location of the nodes as in the previous studies (Noma and IRISAWA 1976a; KoKubun et al., 1980). From these tissue pieces, the myocardial cells underneath the nodal cell layer were carefully separated out under the stereomicroscope. The tissue pieces were then brought into the recording chamber, where after gently tearing apart the remaining connective fibers, they were stirred in normal Tyrode solution to isolate the cells. By this procedure mono-layer cell clusters consisting of 3-10 cells and many single cells were obtained. The isolation of atrial or ventricular cells was done simply by stirring the tissue piece in normal Tyrode solution. After the cells had settled on the floor of the recording chamber, the perfusion of the chamber was started at a rate of $2-3 \mathrm{ml} / \mathrm{min}$. The perfusate prewarmed at $36-37^{\circ} \mathrm{C}$ was led to the inlet of the recording chamber of dimensions $10 \mathrm{~mm}$ in width, $30 \mathrm{~mm}$ in length and $2-3 \mathrm{~mm}$ in depth. The bottom of the chamber was made of a piece of thin glass $(0.1 \mathrm{~mm}$ in thickness). The chamber was fitted into a metal block which kept the temperature of the recording bath at $36-37^{\circ} \mathrm{C}$.

Measurement of membrane potentials, membrane currents and ionophoretic application of acetylcholine. Membrane potentials were recorded by using microelectrodes filled with $3 \mathrm{M} \mathrm{KCl}$, whose resistances were $30-50 \mathrm{M} \Omega$. Even with such a high resistance electrode the penetration procedure often injured the cell when performed simply by pressing the tip on the cell surface. In order to avoid injury on penetration, we first gently pressed the electrode on the cell until small action potentials (less than $5 \mathrm{mV}$ ) were detected or, in the case of a quiescent cell, until the tip resistance was increased by 10-20 M $\Omega$. Under this condition short oscillation (1$2 \mathrm{msec}$ ) of the amplifier could introduce the electrode tip intracellularly. When the penetration was incomplete, the position of the tip was readjusted and the trials were repeated. The two-microelectrode voltage clamp technique (DECK et al., 1964) and the clamp amplifiers were the same as described elsewhere (NomA and Trautwein, 1978). The action potential of the myocardial cell was triggered by a short current pulse through the recording microelectrode using the conventional bridge circuit. The membrane potential was displayed on the storage oscilloscope and was photographed.

ACh was applied ionophoretically using the glass microelectrode filled with $1 \mathrm{M}$ acetylcholine chloride (Sigma), and the electrode was connected to the output of the current injector (DREYER and PEPER, 1974). The measurements were given as mean \pm S.D.

\section{RESULTS}

Size and shape of the nodal cells

The size and shape of the nodal cells were studied by comparison with the myo- 
cardial cells in the storage solution, where most of the cells were rod-like (rod cell) and a few rounded (round cell) as shown in Fig. 1. The isolated cells were either clusters of a few cells or single cells. Clear cross striations were always observed in the rod cell. The nodal cell was characterized by the wide variety in the shape and the small size compared to the ventricular cell and the similarity to the size of the atrial cell (Fig. 1 E). Most of the ventricular cells were rod-type with a thickness of about 10-15 $\mu \mathrm{m}$ (Fig. $1 \mathrm{~K}$ ), while the S-A nodal (Fig. 1 A-D) and the A-V nodal cells (Fig. $1 \mathrm{~F}-\mathrm{J}$ ) were more frequently bifurcated or spindle-like. The size of the rod cells isolated from different tissues are compared in Table 1. In every tissue

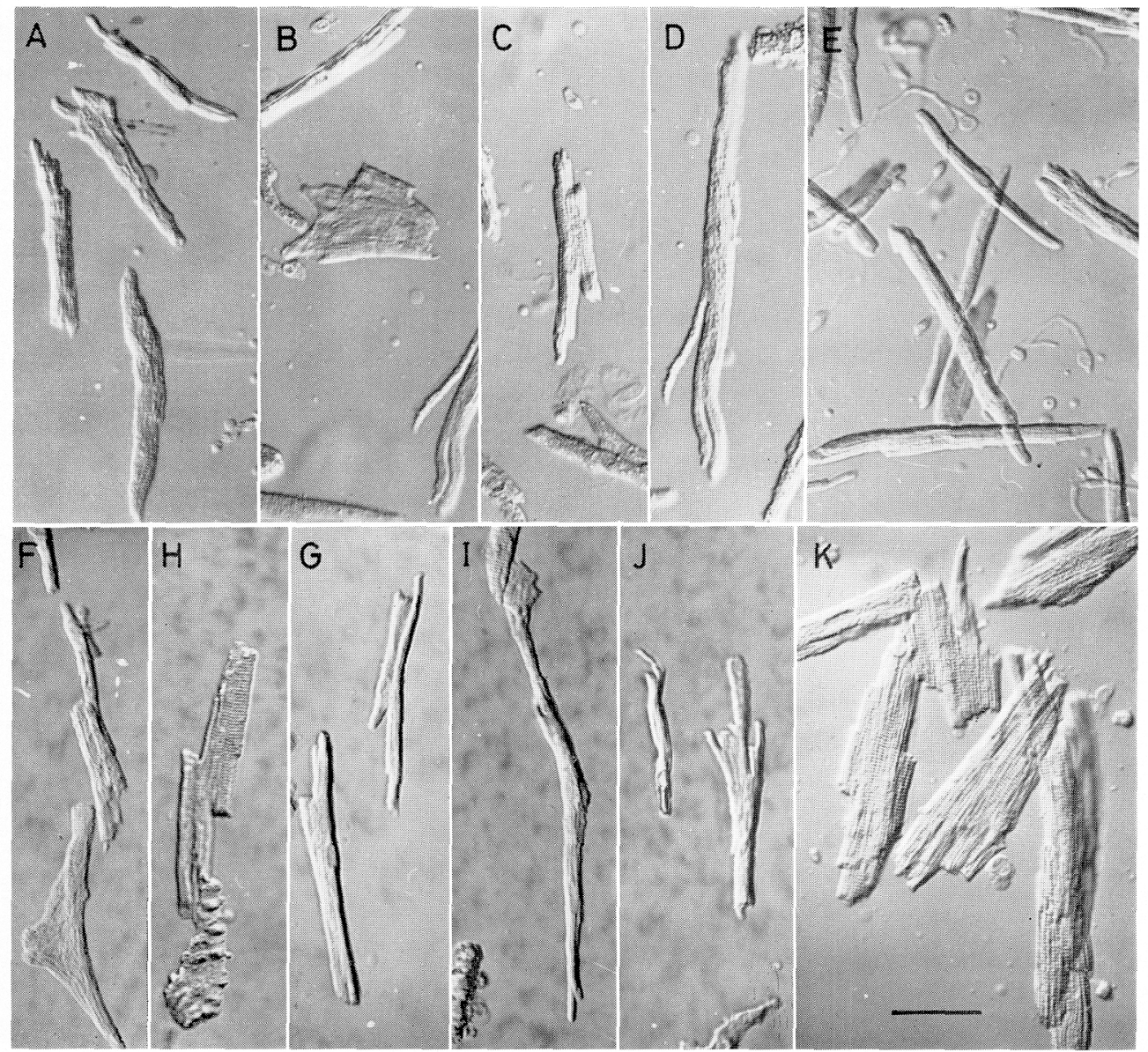

Fig. 1. The photographs of isolated rod cells. Cells were photographed in the storage solution with the differential interference contrast optics at the same magnification. The wide variety of the shape was more often observed in the $S$-A nodal cells (A-D) and in the A-V nodal cells $(F-J)$ than in atrial cells $(E)$ and ventricular cells $(K)$. The round type cells appeared in Plate $\mathrm{H}$ and $\mathrm{I}$. The calibration was $50 \mu \mathrm{m}$. 
Table 1. The size of the rod cells isolated from different tissues.

\begin{tabular}{llcc}
\hline \multicolumn{2}{c}{ Tissue } & Length $(\mu \mathrm{m})$ & Width $(\mu \mathrm{m})$ \\
\hline S-A node & $(n=93)$ & $112 \pm 40$ & $9 \pm 5$ \\
A-V node & $(n=85)$ & $93 \pm 23$ & $14 \pm 6$ \\
Atrium & $(n=166)$ & $94 \pm 26$ & $10 \pm 3$ \\
Ventricle & $(n=102)$ & $115 \pm 33$ & $29 \pm 9$ \\
\hline
\end{tabular}

The measurements are given as mean \pm S.D.

the average length of the cells was about $100 \mu \mathrm{m}$ but the width was significantly smaller in both the S-A nodal and the A-V nodal cells as compared to the ventricular cell.

Action potentials in the isolated cells

On switching the perfusate from $\mathrm{Ca}$-free solution to $1.8 \mathrm{~mm}$ Ca Tyrode, most of the S-A and A-V nodal cells became rounded. Rhythmic beat spontaneously started not only in the rod but also in the round nodal cells. The number of such active cells varied among different experiments. Stable recording of the action potential was easily done from a large cell cluster, while recording from single nodal cells was difficult because of immediate depolarization after penetration of the electrode. In the present study we collected data mainly from small clusters consisting of 310 cells, which were usually composed of round cells. Figure 2 shows spontaneous action potentials recorded from the S-A nodal (Fig. $2 \mathrm{~A}$ ) and the A-V nodal cells (Fig. 2 B). It is obvious that these action potentials are quite similar to those re-

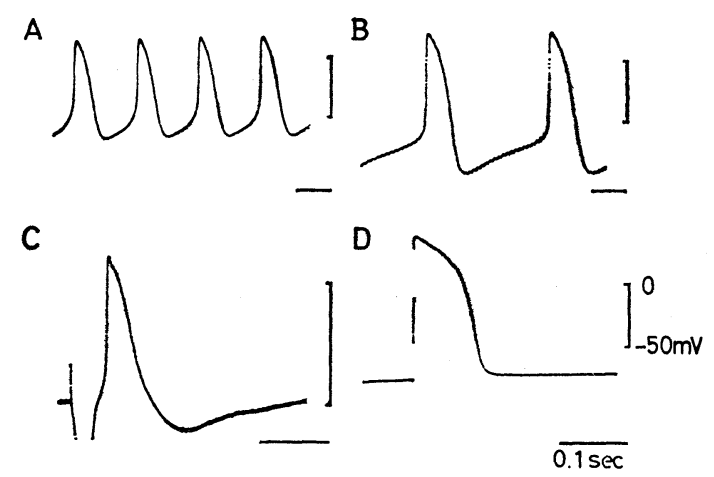

Fig. 2. Action potentials recorded from the cluster composed of 3-10 cells of the S-A node (A), A-V node (B), atrium (C) and ventricle (D). Note different vertical scales and the time bases. The maximum diastolic potential, the overshoot and the duration of the action potential were $-63 \mathrm{mV},+18 \mathrm{mV}$ and $59 \mathrm{msec}$ in the S-A node and $-85 \mathrm{mV}$, $+29 \mathrm{mV}$ and $109 \mathrm{msec}$ in the A-V node, respectively. The resting potential, the amplitude and duration of the atrial action potential were $-43 \mathrm{mV}, 53 \mathrm{mV}$ and $91 \mathrm{msec}$ and were $-78 \mathrm{mV}, 114 \mathrm{mV}$ and $114 \mathrm{msec}$ in the ventricular action potential, respectively. The duration of action potential was measured at half repolarization. 
corded from the conventional preparations. The parameters of the action potentials recorded in $37 \mathrm{~A}-\mathrm{V}$ nodal cell clusters were the maximum diastolic potential $-60.5 \pm 9.2 \mathrm{mV}$, the overshoot $+31.8 \pm 7.5 \mathrm{mV}$, the duration at half repolarization $92.5 \pm 19.2 \mathrm{msec}$, the maximum rate of rise $8.2 \pm 2.5 \mathrm{~V} / \mathrm{sec}$ and the spontaneous rate $178 \pm 48 \mathrm{~min}^{-1}$ at $5.4 \mathrm{~mm}[\mathrm{~K}]_{0}$. These values were not significantly different from those observed in larger A-V nodal preparations (KoKUBUN et al., 1980), indicating that the membrane excitability was well maintained in a small number of the isolated nodal cells even after they became rounded to lose their rod shapes. This is a significant difference compared to the ventricular and the atrial cells, which lost excitability after they became rounded. Even ventricular rod cells often had a low resting potential of 0 to $-20 \mathrm{mV}$. The anodal break excitations were recorded from these depolarized cells without any clear plateau configuration as has been demonstrated by Powell et al. (1980).

In a certain number of single cells or clusters $(2-5$ cells) isolated from the atrium (Fig. 2 C) and ventricle (Fig. 2 D), the usual configuration of the action potential (WEIDMANN, 1956) was recorded. When the ventricular action potential was triggered every $2-3 \mathrm{sec}$, the plateau level when measured $30 \mathrm{msec}$ after the overshoot was $+35.1 \pm 10.9 \mathrm{mV}$, and the duration at half repolarization $242 \pm 77$ $\mathrm{msec}$ at $5.4 \mathrm{~mm}[\mathrm{~K}]_{\mathrm{o}}(n=15)$; these values were $+36.3 \pm 7.7 \mathrm{mV}$ and $182 \pm 64 \mathrm{msec}$ respectively at $10.8 \mathrm{~mm}[\mathrm{~K}]_{\mathrm{o}}(n=10)$. These observations confirmed the normal excitability of the ventricular cell after the treatment with collagenase. The resting potentials were $-70.3 \pm 6.2 \mathrm{mV}$ at $5.4 \mathrm{~mm}$ and $-51.9 \pm 3.8 \mathrm{mV}$ at $10.8 \mathrm{~mm}$ $[\mathrm{K}]_{\mathrm{o}}$, indicating that the resting membrane behaves as a potassium electrode.

\section{Voltage clamp experiments in the nodal cells}

The isolated cells showing action potentials comparable to those of conventional preparations should have intact membrane current systems. This was verified by voltage clamp experiments using the two-microelectrode technique. The clusters consisting of more than 5 cells tolerated the penetration of the second microelectrode for carrying out voltage clamp experiments.

Figures 3 and 4 show the voltage clamp records obtained from an S-A nodal cluster and an A-V nodal cluster, respectively, each composed of 5-10 cells. When the holding potential was set at $-40 \mathrm{mV}$, depolarization activated the slow inward current followed by the delayed activation of the $\mathrm{K}$ current. On repolarization, the $\mathrm{K}$ current decayed with an almost exponential time course, but 2-3 sec elapsed before the current decayed to the steady current level at the holding potential, suggesting that deactivation of a small fraction of the tail current was very slow. The amplitude of the outward current tail increased in proportion to the amplitude of the preceding depolarization and reached a saturation level at $+10 \mathrm{mV}$. The slow inward current became smaller at positive potentials with increasing depolarization and almost disappeared at around $+30 \mathrm{mV}$, as evident from the single exponential increase of the outward current. Hyperpolarization of the A-V nodal cell 


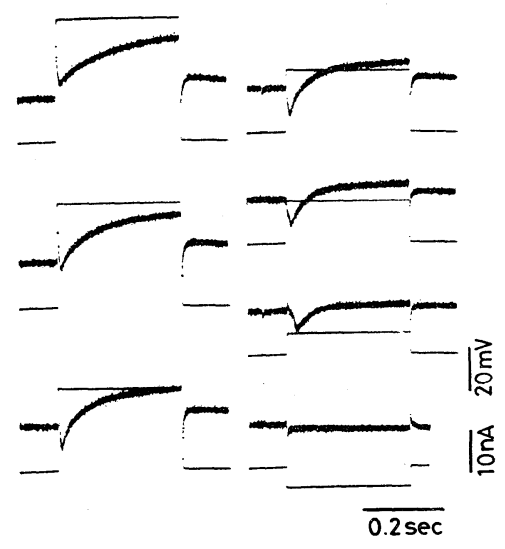

Fig. 3. Voltage clamp experiments on the flat S-A nodal cell cluster, about $60 \mu \mathrm{m}$ in both width and length. The holding potential was $-40 \mathrm{mV}$ and the clamp pulses were applied in $10 \mathrm{mV}$ steps from -50 to $+20 \mathrm{mV}$. The traces were photographed from the storage oscilloscope.

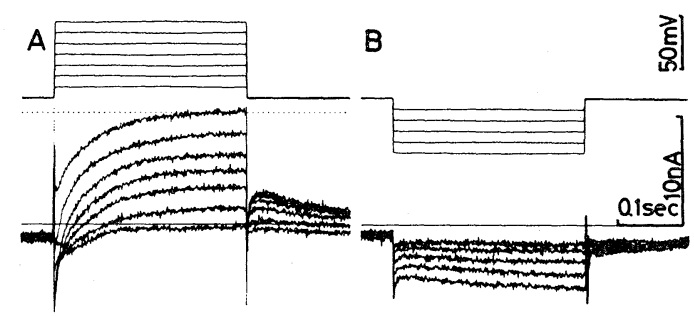

Fig. 4. Voltage clamp experiments in the flat A-V nodal cell cluster, about $50 \mu \mathrm{m}$ in width and $100 \mu \mathrm{m}$ in length. The holding potential was $-40 \mathrm{mV}$ and the clamp pulses were applied in $10 \mathrm{mV}$ steps at the depolarization $(-30$ to $+30 \mathrm{mV})$ and the hyperpolarization $(-90$ to $-50 \mathrm{mV})$. The traces were superposed on the $X-Y$ recorder from the memory block of the computer (Nicolet M-80). The straight lines on the current traces represent 0 level and the dotted line $10 \mathrm{nA}$ outward.

membrane caused a slowly increasing inward current. The amplitude of this change in inward current was very small compared to the S-A nodal multicellular preparations or some of the A-V nodal preparations (YANAGIHARA and IRISAWA, $1980 \mathrm{a}$; NomA et al., 1980a). The cell clusters, nevertheless, were spontaneously active, supporting the hypothesis that the inward current activated during hyperpolarization does not significantly contribute to the pacemaker depolarization (YANAGIHARA et al., 1980; Noma et al., 1980b; YANAGIHARA and IRISAWA, 1980a). Thus, it is evident that the pattern of the voltage clamp records remained very similar to that obtained in the larger conventional nodal preparations. The amplitude of the currents in the present preparation was 5-10 times lower than that previously reported for larger preparations. 


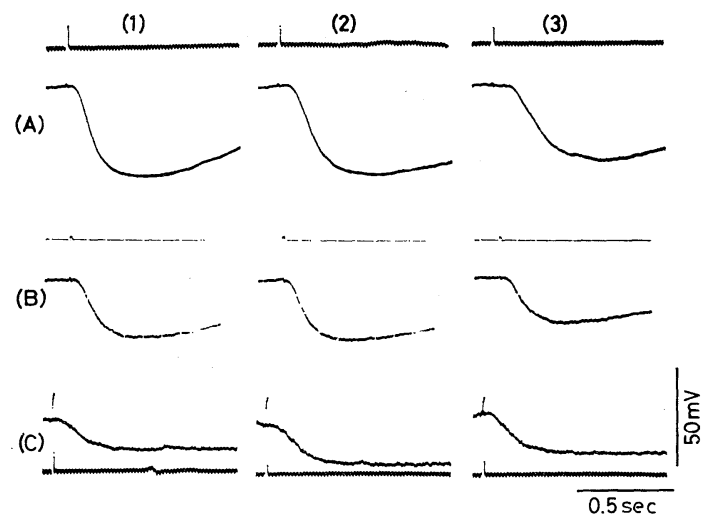

Fig. 5. Hyperpolarizing responses to the ionophoretic application of $\mathrm{ACh}(10 \mathrm{msec}$ and $9 \mathrm{nA}$ current pulse). The current pulses were indicated by the upward jump of the straight line in each record. The top row obtained from the S-A nodal cell cluster, the ACh pipette was attached to the cell surface (1), $12 \mu \mathrm{m}$ apart from the cell (2), $25 \mu \mathrm{m}$ apart (3). The middle and bottom rows from the A-V nodal and atrial cell clusters, respectively; the pipette was attached to 3 different sites of the specimen.

\section{Sensitivities of isolated cells to neurotransmitters}

Although the above observations suggested that the membrane excitability was retained intact, the proteolytic enzyme treatment might have affected the reaction of the receptor proteins to the neurotransmitters. Therefore, we examined the responses of the isolated cell to $\mathrm{ACh}$ and epinephrine. The advantage of using isolated cell preparations is that we can apply ACh to the cell surface from a source at a measured distance. Figure 5 shows hyperpolarizations of the membrane in quiescent cells of the S-A node (A), the A-V node (B) and the atrium (C) in response to ACh applied ionophoretically by a short current pulse (10 msec, $9 \mathrm{nA}$ ) through the $\mathrm{ACh}$ pipette. When the pipette tip was positioned very close or even attached to the surface of the cell, the ACh response occurred as fast as had been demonstrated in the small tissue pieces of the S-A node (OSTERRIEDER et al., 1980). The hyperpolarization started with a sigmoidal time course and a clear bend of the trace occurred within $30 \mathrm{msec}$. Such a quick response was observed even when the pipette tip was moved to different sites on the cell surface within the same cell cluster (Fig. $5 \mathrm{~B}, \mathrm{C}$ ). A clear latency occurred only when the tip was withdrawn by 12 and $25 \mu \mathrm{m}$ from the cell surface (Fig. $5 \mathrm{~A}$ ). These findings agree with the demonstration of a homogeneous distribution of the muscarinic receptors by autoradiography (HARTZELL, 1980).

The degree of sensitivity to ACh was also studied by perfusing the spontaneously active cell clusters with a given concentration of ACh. $10^{-7} \mathrm{M}$ ACh significantly decelerated the spontaneous firing rate of the S-A node from 255 to 200 $\min ^{-1}$ (Fig. 6) and the cell became quiescent at $2 \times 10^{-7} \mathrm{M} \mathrm{ACh}$. At the same concentration such changes in rate occurred in conventional preparations only when 

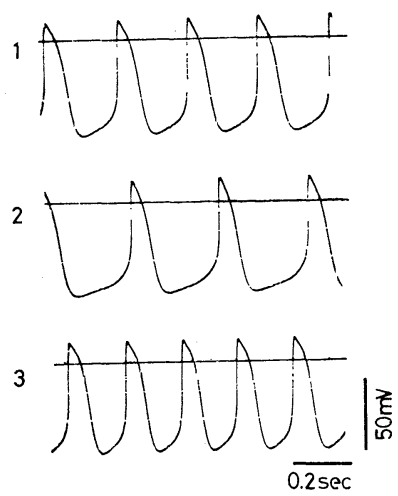

Fig. 6. Modification of the spontaneous action potential of the S-A nodal cell cluster by $10^{-i}$ M ACh (2) and by $5.5 \times 10^{-6} \mathrm{M}$ epinephrine (3). In the control (1) the maximum diastolic potential, the overshoot and the frequency were $-68 \mathrm{mV},+13 \mathrm{mV}$ and $255 \mathrm{~min}^{-1}$ respectively. The effects were all reversible on washing out the drug.

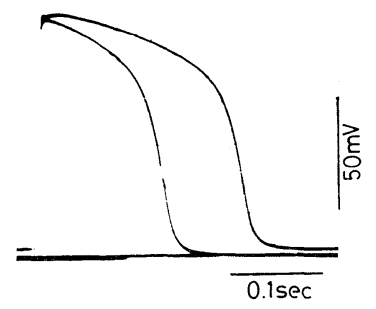

Fig. 7. Effects of $5.5 \times 10^{-6} \mathrm{M}$ epinephrine on the action potential of a single ventricular cell. The action potential was triggered by short depolarizing current pulse through the microelectrode. Note the plateau length at half repolarization was prolonged from 132 to $213 \mathrm{msec}$ and the plateau level was elevated by epinephrine.

they were treated with cholinesterase inhibitors (OSTERRIEDER et al., 1980), suggesting that the endogenous cholinesterase was washed out during the isolation procedure.

The isolated cells also showed the usual responses to epinephrine. Clear acceleration (Fig. 6-3, from 255 to $323 \mathrm{~min}^{-1}$ ) of the spontaneous firing rate of the S-A nodal or the A-V nodal cell (not shown) was evident when the perfusate contained epinephrine in a concentration of $5.5 \times 10^{-6} \mathrm{M}$. In the case of the ventricular cell, the application of epinephrine elevated the plateau level and prolonged the duration of the action potential (Fig. 5, from 132 to $213 \mathrm{msec}$ at half repolarization).

The above findings clearly showed that the receptor molecules for $\mathrm{ACh}$ or epinephrine were not impaired by the isolation procedure of the cardiac cells using collagenase.

\section{DISCUSSION}

It was found that the isolated cells from both the S-A node and the A-V node 
showed rod and round configurations. Evidently most of the round cells were deformed by the isolation procedure. It remained unknown whether some of the round cells were in their intact shape and corresponded to the "typical nodal cell." In his histological study KAWAMURA (1961) visualized "typical nodal cells" which were irregular and roughly spindle shaped and sometimes branching with thin tapering ends. These morphological characteristics were observed in the isolated nodal cells, except that the living cells in Ca-free solution appeared more slender compared to the histological appearance.

Some of the rounded nodal cells resumed spontaneous action potentials and contractions. In this respect nodal cells resembled the embryonic heart cells which resumed spontaneous activity even when they were deformed after trypsin treatment (DehaAn and Gottlieb, 1968; Goshima, 1971). This is in strong contrast to the ventricular cell which lost excitability after becoming rounded. Furthermore, even rod cells of the ventricle frequently lost the plateau phase of the action potential and often had less negative resting potentials if they were not incubated in storage solution (Powell et al., 1980). The incubation in this solution was very helpful for maintaining the normal activity of ventricular cells (ISENBERG and KLöCKNER, 1980). However, action potentials were obtained from the isolated nodal cells even without incubation in the storage solution and immediately after isolation. Thus, it may be concluded that nodal cells, especially A-V nodal cells, can tolerate the isolation treatment better than cells of the working myocardium.

The reason for the depolarization of many isolated cells is not totally clear. In some of the isolated cells, the measurements of the nodal and ventricular action potential were quite comparable to the data obtained from the tissue pieces. In addition to these observations, the spontaneous action potentials were continuously recorded for more than $2 \mathrm{hr}$ in nodal tissue pieces during superfusion of the collagenase-containing normal Tyrode (unpublished observation). These findings suggested that the depolarization could not be attributed to the direct effect of collagenase on the membrane ionic channels.

The preliminary clamp data obtained in this study were quite similar to those recorded in the conventional preparations in spite of the fact that the ratio of the membrane facing the intercellular cleft to the total cell surface should be much smaller than the conventional preparations. This finding clearly suggests that the record obtained from the conventional preparation was not significantly affected by the accumulation or depletion of ions in the intercellular space or by the failure in the spatial clamp. This view well agrees with the previous observations that the voltage homogeneity during the voltage clamp was well achieved in the conventional preparation except for 5-10 msec after the onset of the clamp pulse (NomA and IRISAWA, 1976a; NomA et al., 1980a).

The onset of ACh-induced hyperpolarization was recorded with measured distances between the tip of the ACh pipette and the cell surface in the present study. The onset was much faster than previously reported (HARTZELl et al., 
1977; Glitsch and PotT, 1978; Hill-Smith and Purves, 1978) and was quite similar to that recorded by OSTERRIEDER et al. (1980) and NOMA et al. (1981). The latter authors suggested that the latency and the time course of the response could be explained by both the slow kinetics of the ACh-induced $\mathrm{K}$ channel and diffusion of ACh into the receptors which are distributed with a low density over the cell surface.

With the present isolation technique the yield of the active cell varied between different experiments. Also, with the isolated preparations the recording was frequently interrupted by the dislodgement of the electrode caused by the twitch contraction or mechanical vibrations. Once the electrode was dislodged, most cells were seriously injured and thus a long recording was difficult, especially in the voltage clamp experiment. In spite of these technical difficulties, it is obvious that the isolated cardiac cell preparation has advantages in various aspects when compared with the conventional multicellular preparation. In the isolated cell preparations, the voltage homogeneity during the voltage clamp was well established, the drug could be applied more directly to the cell, and intracellular injection of drugs should be possible.

The authors thank Prof. W. Trautwein for his fruitful comments and suggestions on the experiments and for preparing the manuscript and also thank Dr. T. Nakamura and Prof. Y. Tonomura for supporting the study. The technical assistance of Mr. O. Nagata and Mr. M. Ohara is highly appreciated.

\section{REFERENCES}

Brown, A. M., LeE, K. S., and Powell, T. (1980) Reactivation of sodium conductance in single heart muscle cells. J. Physiol. (Lond.), 301: 78P-79P.

Brown, H. and DiFrancesco, D. (1980) Voltage-clamp investigations of membrane currents underlying pace-maker activity in rabbit sino-atrial node. J. Physiol. (Lond.), 308: 331-351.

Deck, K. A., Kern, R., and Trautwein, W. (1964) Voltage-clamp technique in mammalian cardiac fibres. Pflügers Arch., 280: 50-62.

DehaAn, R. L. and GotTlieb, S. H. (1968) The electrical activity of embryonic chick heart cells isolated in tissue culture singly or in interconnected cell sheets. J. Gen. Physiol., 52: 643665.

DiFrancesco, D., Noma, A., and Trautwein, W. (1979) Kinetics and magnitude of the timedependent potassium current in the rabbit sinoatrial node: Effect of external potassium. Pflügers Arch., 381: 271-279.

DreYer, F. and PePER, K. (1974) Iontophoretic application of acetylcholine; Advantages of high resistance micropipettes in connection with an electronic current pump. Pflügers Arch., 348: $263-272$.

Gurtsch, H. G. and Poтt, L. (1978) Effects of acetylcholine and parasympathetic nerve stimulation on membrane potential in quiescent guinea-pig atria. J. Physiol. (Lond.), 279: 655-668.

GoshimA, K. (1971) Synchronized beating of myocardial cells mediated by FL cells in monolayer culture and its inhibition by trypsin-treated FL cells. Exp. Cell Res., 65: 161-169.

Hartzell, H. C., Kuffler, S. W., Stickgold, R., and Yoshikami, D. (1977) Synaptic excitation and inhibition resulting from direct action of acetylcholine on two types of chemoreceptors on individual amphibian parasympathetic neurones. J. Physiol. (Lond.), 271: 817-

Vol. 31, No. 4, 1981 
846.

Hartzell, H. C. (1980) Distribution of muscarinic acetylcholine receptors and presynaptic nerve terminals in amphibian heart. J. Cell Biol., 86: 6-20.

Hill-Smith, I. and Purves, D. R. (1978) Synaptic delay in the heart; an ionophoretic study. J. Physiol. (Lond.), 279: 31-54.

ISENBERG, G. and KLöCKNER, U. (1980) Glycocalyx is not required for slow inward calcium current in isolated rat heart myocytes. Nature, 284: 358-360.

Kawamura, K. (1961) Electron microscope studies on the cardiac conduction system of the dog. II. The sinoatrial and atrioventricular nodes. Jpn. Circ. J , 25: 973-1013.

Kokubun, S., Nishimura, M., Noma, A., and Irisawa, H. (1980) The spontaneous action potentials of the rabbit atrioventricular node cells. Jpn. J. Physiol., 30: 529-540.

Lee, K. S., Weeks, T. A., Kao, R. L., Akaike, N., and Brown, A. M. (1979) Sodium current in single heart muscle cells. Nature, 278: 269-271.

Noma, A. and Irisawa, H. (1976a) Membrane currents in the rabbit sinoatrial node cell as studied by the double microelectrode method. Pflügers Arch., 364: 45-52.

Noma, A. and IrisawA, H. (1976b) A time- and voltage-dependent potassium current in the rabbit sinoatrial node cell. Pflügers Arch., 366: 251-258.

Noma, A., YANAGIHARA, K., and IrISAWA, H. (1977) Inward current of the rabbit sinoatrial node cell. Pflügers Arch., 372: 43-51.

Noma, A. and Trautwein, W. (1978) Relaxation of the ACh-induced potassium current in the rabbit sinoatrial node cell. Pflügers Arch., 377: 193-200.

Noma, A., Peper, K., and Trautwein, W. (1979) Acetylcholin-induced potassium current fluctuations in the rabbit sino-atrial node. Pflügers Arch., 381: 255-262.

Noma, A., Irisawa, H., Kokubun, S., Kotake, H., Nishimura, M., and Watanabe, Y. (1980a) Slow current systems in the A-V node of the rabbit heart. Nature, 285: 228-229.

Noma, A., Kotake, H., and Irisawa, H. (1980b) Slow inward current and its role mediating the chronotropic effect of epinephrine in the rabbit sinoatrial node. Pflügers Arch., 388: 1-9.

NomA, A., Kokubun, S., and TANiguchi, J. (1981) Ionic mechanism underlying muscarinic response in the rabbit S-A node. J. Physiol. (Paris), in press.

Osterrieder, W., Noma, A., and Trautwein, W. (1980) On the kinetics of potassium channel activated by acetylcholine in the S-A node of the rabbit heart. Pflügers Arch., 386: 101-109.

Osterrieder, W., YANG, Q. F., and Trautwern, W. (1981) The time course of the muscarinic response to ionophoretic ACh application to the S-A node of the rabbit heart. Pflügers Arch., 389: 283-291.

Powell, T., Terror, D. A., and Twist, V. W. (1980) Electrical properties of individual cells isolated from adult rat ventricular myocardium. J. Physiol. (Lond.), 302: 131-153.

YANAGIHARA, K. and IRISAWA, H. (1980a) Inward current activated during hyperpolarization in the rabbit sinoatrial node cell. Pflügers Arch., 385: 11-19.

Yanagihara, K. and Irisawa, H. (1980b) Potassium current during the pacemaker depolarization in the rabbit sinoatrial node cell. Pflügers Arch., 388: 255-260.

YANAGIHARA, K., NomA, A., and IrISAwA, H. (1980) Reconstruction of sino-atrial node pacemaker potential based on the voltage clamp experiments. Jpn. J. Physiol., 30: 841-857.

Vahouny, G. V., Wei, R., Starkweather, R., and Davis, C. (1970) Preparation of beating heart cells from adult rats. Science, 167: 1616-1618.

Weidmann, S. (1956) Electrophygiologie der Herzmuskelfaser, Huber, Bern, p. 20. 